( ) Journal of Open Innovation: Technology, Market, and Complexity a SpringerOpen Journal

\title{
RESEARCH
}

Open Access

\section{Study on CEO characteristics for management of public art performance centers}

\author{
Joon-ho Kim ${ }^{1 *}$ and Seung-hye Jung ${ }^{2}$
}

\author{
* Correspondence: 126r3bn@ \\ hanmail.net \\ ${ }^{1}$ Garam Education, Jam-sil the shop \\ Starpark A-309, Shincheon-Dong \\ 714, Songpa-Gu, Seoul, Korea \\ Full list of author information is \\ available at the end of the article
}

\begin{abstract}
The purpose of this study is to present the rationale and empirical evidence as to whether the characteristics of chief executive officer (CEO), such as entrepreneurship, social responsibility (perception), and social capital, at public art performance centers have effect on management outcomes, and to find if quality management activities have significant effects on business performance. The analysis was carried out with the structural equation model by using the survey data on 98 CEOs at public art performance centers. After the analysis, it was shown that the entrepreneurship, social responsibility (perception), and social capital have positive $(+)$ effects on quality management activities, and quality management activities have positive $(+)$ effects on business performances (market performance, financial performance). Therefore, as the local cultural center, the public art performance centers should take social responsibility and role, while being financially productive through effective operation. Furthermore, CEO of public art performance centers should have expertise in the fields of art and performances, productions, and advertising. For the management and enhancement, entrepreneurship and broad social network is also necessary.

Keywords: Public art performance centers; CEO; Entrepreneurship; Social responsibility; Social capital; Quality management activities; Business performance
\end{abstract}

\section{Introduction}

Art management is a "catalytic activity" that brings art and audience together (Lee 2009a). The objective of art management is to expose more people to more culture and arts in more places; in other words, the goal is to maximize enjoyment of arts (Lee 2009b). Art management has been gaining traction in the field of culture and arts as the gravity of business performance has now come to the fore. Many people's basic living standards have risen since the 2000s, resulting in a boost in self-actualization desires. Amid prevailing desires to further improve the quality of life, various performance centers have become an essential factor in such efforts, subsequently being established as a readily accessible cultural space (Lee and Chung 2010). Moreover, escalating desires for culture and arts compelled local government units to establish arts performance centers; as of 2012, 170 out of

(C) 2015 Kim and Jung. Open Access This article is distributed under the terms of the Creative Commons Attribution 4.0 International License (http://creativecommons.org/licenses/by/4.0/), which permits unrestricted use, distribution, and reproduction in any medium, provided you give appropriate credit to the original author(s) and the source, provide a link to the Creative Commons license, and indicate if changes were made. 
234 local government units in Korea established and are operating such art centers (The Korean Cultural and Art Centers Association 2013).

In the culture and arts field, a public performance center is the platform via which arts performance producers and consumers interact, and which culture and arts is promoted and developed. Most notably, it is the location in which local culture policies actually come to life. However, public performance centers in real life fall short of these expectations. According to Lee (2009a)), they severely lack in professional manpower, thereby hampering active planning and execution of new projects by the performance center itself. As a result, these facilities are only passively utilized for rental revenue. Moreover, unnecessary or redundant administrative processes and red tapes thwart efforts to mobilize external financial resources. Finally, Lee (2009b)) argues, public performance centers are overly fixated on increasing rents and only recruiting large-scale performances to secure finances, disregarding their roles as a space provider for local residents and artists.

Hence, this study performs an empirical analysis of the effects of quality management on business performance, in an attempt to ameliorate the business performance of public performance centers. For the analysis, the characteristics of corporate CEOs (antecedents of quality management) were sub-divided into entrepreneurship, social responsibility, and social capital. The significance of quality management is generally accentuated in the field of corporate management, and management of public performance centers is only understood under the context of art management. Moreover, studies on the relationship of quality management and business performance are scanty. The reason for such low recognition of quality management in public performance center management is that quality management has been perceived as an efficient management innovation program for firms for profit, such as manufacturing or service industries. In other words, quality management has been regarded as irrelevant to management of public performance centers that operate to realize publicness, not for profit. Quality management is an innovation program that facilitates change toward promoting employee-oriented operations, problem solving, and stakeholder and organizational values (Ghobadian and Gallear 1996). This system is a step toward the realization of economic performance and integration of humans and social systems. That is to say, quality management is not a management system solely for the purpose of generating profit; but rather, it is a holistic management system to ultimately boost management efficiency by enhancing the qualities of products and services via consistent management innovation and increasing employee and consumer satisfactions. Therefore, quality management can be an imperative management innovation activity in art management. As previously discussed, the primary purpose of public performance centers is to further culture and arts, namely for local regions, via performing the role as the central institution that realizes local culture and arts policies. To this end, public performance centers must meet the needs of culture and arts providers and consumers, as well as invigorating their potential or prospective needs. Thus, quality management is a critical factor for public performance centers as much as for general firms for profit. It is widely discussed that the characteristics of a CEO are integral predisposing factors for the success of quality management. This is because the CEO of an organization is a key individual that disseminates the organization's values and direction, expected performance, consumer- and stakeholder-oriented management, organizational learning and management innovation within the organization, and encourages and motivates the members of the organization to perform such expectations (McAdam 1999). 
Against this backdrop, the objective of the present study is to determine if the characteristics of the CEOs of public performance centers and quality management significantly affect business performance, and to identify the structural relationship among them. We established two research questions so as to accomplish this objective: first, can preceding studies that have identified that CEO's characteristics significantly affect quality management be applied to public performance centers in the culture and arts sector?; second, does quality management have a significant effect on business performance of public performance centers as displayed in general firms? By dividing the characteristics of a CEO into entrepreneurship, social responsibility, and social capital, we investigated to find if these variables have a positive effect on quality management, and also if the quality management has a positive effect on business performance. Along with the study findings indicating that quality management and the basic characteristics required for a public performance center CEOs are indeed as critical as for general firms to improving business performance, we also suggest some practical implications in enhancing business performance of public performance centers based on these findings.

\section{The characteristics of CEOs in the arts industry and quality management The characteristics of CEOs in the arts industry}

Arts entrepreneurs refer to entrepreneurs who translate arts visions into tangible forms (e.g., services) to provide to the general public (Wilson and Stokes 2002). In other words, an arts entrepreneur is interested in whether a particular arts activity can reap profits by meeting consumer demands, as much as the activity per se (Rae 2005). In this perspective, the CEOs in the arts industry also must possess the characteristics of CEOs of general firms, because art management involves producing profits via satisfying consumers' culture and arts desires and needs. Notwithstanding these requirements for arts CEOs, art management is distinctly differentiated from general firms by the specificity of the culture and arts industry and the primary purpose of publicness (i.e., maximizing enjoyment of arts), in addition to the goal of generating profits. Therefore, an arts CEO must possess certain distinctive characteristics apart from that of general firm CEOs.

Therefore, first, entrepreneurship is an important factor in enhancing the performance of public performance centers, and can be understood as a vital characteristic a CEO must possess. It is defined as the process or behavior of starting a new business with innovative qualities, managing and improving an existing organization, and producing desirable outcomes (Burgelman 1984; Baron and Shane 2007). In the context of the arts industry, entrepreneurship can be defined as the process of acquiring an intellectual property produced by an artist and transforming it into a final product with economical innovation, or the process of incorporating new market value into a creative output (de Bruin 1998). Such entrepreneurship is propounded as an essential characteristic for arts CEOs due to the criticism that an arts CEO generally displays vast personal preferences (Kamara 2006) and relatively lack entrepreneurial capacity compared to their creative competence (Koivunen and Kotro 1998). As these issues directly affect the competitiveness and profitability of art management, many contend that the lack of entrepreneurship with regard to managerial competence and perception and behaviors of business operations is the largest stumbling block for raising competitiveness and profitability (NESTA 2007). 
Meanwhile, the purpose of publicness, which is to maximize enjoyment of arts in a community, is as important as boosting competitiveness and profitability in art management. Hence, it can be said that social responsibility is one of the most fundamental psychological quality required for a public performance center CEO. Social responsibility refers to the willingness to contribute to foster a sustainable economical development via working with society, local community, family and employees, to ultimately improve quality of life (World Business Council for Sustainable Development WBCSD 1999). In other words, social responsibility is a mindset and behavior that promotes stakeholders' values. Most preceding studies on performing social responsibility were conducted on general firms, and reported that performing social responsibility has positive effects on the firm's evaluation and value (Brown and Dacin 1997; Sen and Bhattacharya 2001; Lee and Chung 2005), as well as on its members' satisfaction and engagement (Brammer, Millington, and Rayton 2007; Boddy et al. 2010). The concept of social responsibility also is in line with that of publicness of public performance centers. Social responsibility is underscored in the publicness functions of public performance centers, as public performance centers must serve as the central institution that fosters local communities of culture and arts (Lee 2006), a performance center that is readily available for everyone regardless of income or class (Jeon et al. 2003), and an institution that facilitates the realization of local culture and welfare as well as invigorating cultural education (Lee 2009a).

Moreover, interpersonal competence is suggested as one of the competences of a corporate CEO that plays a decisive role in firm growth and development (Herron and Robinson 1993). This denotes the significance of a CEO's social network in corporate management. Likewise, an art CEO's social network is also highlighted in art management. In fact, social networks are indispensable in terms of the creation, production and distribution of culture and arts products. This is due to the fact that art management activities are formed by interdependent relationships among the participants and that they are largely governed by social networks (Faulkner and Anderson 1987; Park and Lim 2008).

\section{Art management and quality management activities}

Quality management is also an innovative application to art management. Art CEOs must maintain a harmonized balance among profitability, publicness, and artistry, which is in line with the fundamental concepts of quality management: first, quality management promotes an organization's goals and human-oriented business processes; second, the quality in quality management encompasses material and human resources, and it includes quality of all tangible items as well as that of humans, culture, and corporate objectives; third, the quality characteristics of goods and services are defined by customers' needs; fourth, quality management aims at establishing a human-oriented management system that produces customer satisfaction; fifth, quality management is a management technique via which organizational cultures are improved and future-oriented business development are promoted (Ko 2012).

In essence, the concepts of quality management can be applied to the goals of art management as follows. First, quality management is exceedingly human-oriented and 
ultimately promotes customer satisfaction. This is comparable to the goal of publicness in art management, as art management seeks to improve the quality of human lives by satisfying consumers' desires for enjoying culture and arts (Lee and Chung 2010). In fact, art management promoting happiness by improving people's quality of life is also identical to the concept of customers' happiness advocated in quality management. Second, the concept of quality as referred to in quality management is a comprehensive concept as that of the quality of culture, in which customers are the evaluators. This is in consonance with art management promoting artistry. That is, because artistry is what satisfies consumers' artistic desires, it is not solely determined by the artist's personal capacity, but rather by an interdependent relationship among creation, production and distribution (Goo 2008). Therefore, artistry can be considered as a comprehensive concept as quality in quality management. Third, quality management is an activity designed to improve business processes to achieve high profit and low cost, as well as customer satisfaction (Goetsch and Davis 1994). Art management also aspires to achieve the same-to promote profitability via management efficiency. Hence, as much as quality management is integral to general firms, it is equally critical in art management as well, namely public performance centers, to improve performance via management efficiency.

\section{Research models and hypotheses}

As noted thus far, the characteristics of a CEO are antecedents of the outcome of quality management. Correspondingly, previous studies contend that a CEO's strong support of quality management is crucial to the execution and development of quality management activities (McAdam 1999). Moreover, because quality management promotes customer satisfaction via innovation (Goetsch and Davis 1994), it can be predicted that it will have a significant effect on business performance. Thus, we designed a research model as shown in Fig. 1.

\section{The relationship between entrepreneurship and quality management activities}

The exact definition of entrepreneurship is still in dispute, as the subjects and levels of analyses are different for each scholar. Some scholars define entrepreneurship as a process of promoting opportunities without being governed by controllable resources

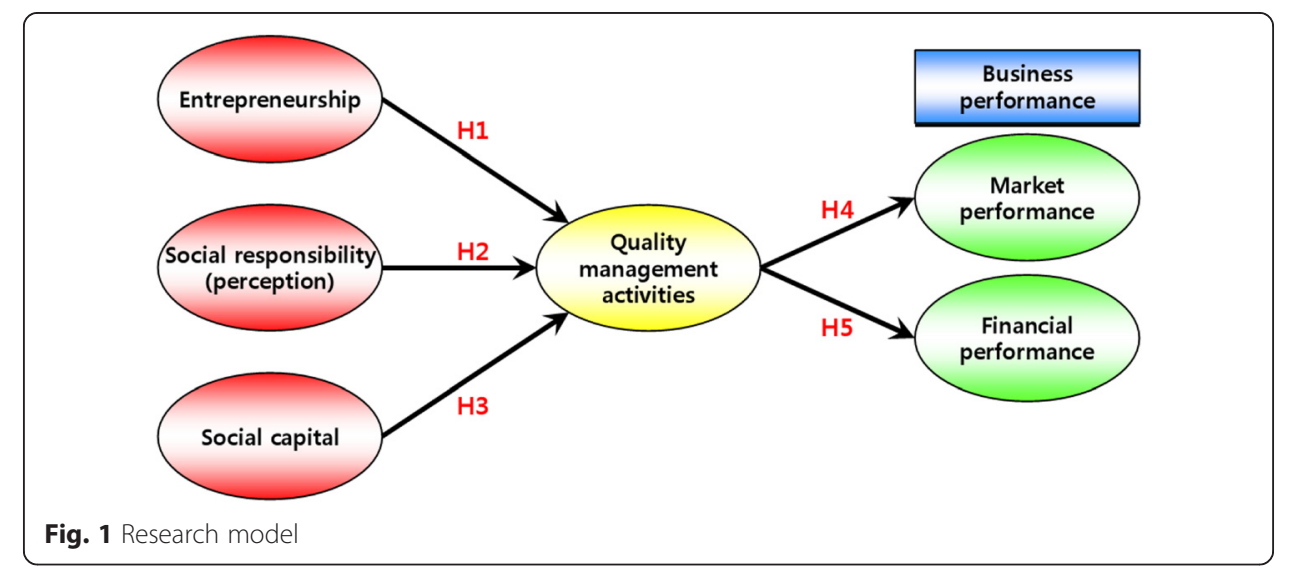


(Stevenson and Jarillo 1990); some define it as the creation of new organizations (Gartner 1985), while some define it as a corporate activity to explore and execute to create something new (Baron and Shane 2007); On the other hand, still others define entrepreneurship as the creation of new business, that is, activities to harness opportunities in markets by expanding organizational capacity and integrating newly produced internal resources (Burgelman 1984). In essence, entrepreneurship can be defined as a starting-up of a new business with innovativeness, management and improvement of existing organizations, and activities to facilitate outcome.

The sub-dimensions of entrepreneurship are innovativeness, risk taking, and proactiveness (Covin and Slevin 1986; Matsuno et al. 2002). Innovativeness is a process through which entrepreneurs transform market-oriented ideas into an opportunity. It signifies newness and uniqueness, which allow firms to be efficient and distinguished from competitors. Risk taking refers to a propensity towards promoting risks; it describes the level of willingness to aggressively pursue something despite prevailing uncertainty, or the degree of insensitivity towards or enjoyment of risks. Proactiveness defines a future-oriented viewpoint, or a tendency for aspiring to obtain leadership by anticipating and promoting new opportunities and exploiting emerging markets.

Entrepreneurship, as one of the characteristics of a CEO, thus plays an important role in quality management activities. The constructs of entrepreneurship (i.e., innovativeness, risk taking, and proactiveness) can also be considered as preceding variables of willingness to perform quality management activities, which means that these factors can also have a vast effect on quality business performance. The implementation of quality management per se, is a display of risk taking behavior and promoting innovativeness, and it is correlated with the characteristics of the CEO. In other words, quality innovation management is dictated by the characteristics of the CEO of an organization, which has been suggested as important situational factors of quality management (Lawler et al. 1992).

Shin et al. (1998) asserted that innovativeness is a tendency for executing and willing to experience creational ideas and that it positively affects innovative quality management activities, such as product development or product innovation. Schriesheim and Cogliser (2009) suggested that because quality innovation is not achieved via a phased process of sequential steps, but via a committed performance of quality innovation factors, firms with CEOs that are highly proactive are more likely to execute quality management activities. Furthermore, risk taking, which is a tendency for audaciously trying out unfamiliar methods of quality innovation, has a great effect on quality management activities because it allows firms to beat their competitors to developing and launching new products that are meaningful to customers, which in turn attenuates the uncertainty about the future of the company (Schriesheim and Cogliser 2009). Therefore, based on these discussions, we established the following hypothesis regarding entrepreneurship and quality management activities:

\section{Hypothesis 1}

Entrepreneurship of public performance center CEOs will have a positive effect on quality management activities. 
The relationship between the perception of social responsibility and quality management activities

Bowen (1953) was the first to suggest an academic definition of corporate social responsibility (CSR). Since then, there have been many studies on CSR and suggestions of its definition, without much success in establishing a single, agreed definition. Even the terms related to the concept of social responsibility are used in a variety of ways, such as corporate responsibility or responsible business, corporate citizenship, corporate sustainability, corporate ethics, and sustainable entrepreneurship (Kim and Kim 2010). The World Business Council for Sustainable Development (World Business Council for Sustainable Development WBCSD 1999) defined corporate social responsibility as the "continuing commitment by business to contribute economic development while improving the quality of life of the workforce and their families as well as the community and society at large". The most commonly used definition of corporate social responsibility is that from The European Commission in 2001, that social responsibility is an integrating concept that requires firms to "have in place a process to integrate social, environmental, ethical human rights and consumer concerns into their business operations and core strategy in close collaboration with their stakeholders" (Preuss, Haunschild, and Matten 2009). This definition presents CSR in the viewpoint of stakeholders (i.e., members of society). That is, corporate social responsibility can be seen as a corporate activity that aims at elevating the firm's value (Donaldson and Preston 1995).

Carroll (1991) and Maignan (2001) propounded four sub-dimensions of corporate social responsibility: economical responsibility, which is based on creating profit; legal responsibility, which demands law-abiding practices; ethical responsibility, which compels to do what is right and fair, and charitable responsibility, which demands donating resources to local communities to improve the quality of life.

Corporate social responsibility pertains to quality management. Quality management is a comprehensive management tactic to achieve performance via customer satisfaction. Previous studies suggest that CSR can have a positive effect on achieving such quality management goals. It has been found that CSR enhances a firm's reputation and image (Brown and Dacin 1997; Sen and Bhattacharya 2001), and also positively affects employee satisfaction and organizational commitment (Brammer et al. 2007). Moreover, it has been proffered that CSR has positive effects in enhancing the qualities of products or services (Kim et al. 2011). Most notably, CSR affects customers' perception of quality, and is an important factor in customer satisfaction (Kim and Yoon 2011). Integrating these studies together, CSR not only increases a firm's reputation but also increases quality by prompting employee satisfaction, which ultimately leads to customer satisfaction. In the cases of public performance centers, in particular, CSR is more highlighted than in the cases of general firms because the core objective of public performance centers is to improve the quality of lives of local residents via expanding their enjoyment of arts (Lee 2006). As has been noted, the effect of CSR on customer satisfaction is translated into the public performance center industries, with public performance center CEOs' perception of CSR directly affecting customer satisfaction. Given these points, it can be predicted that public performance center CEOs' perception of CSR holds an intimate relationship with quality management. Therefore, we established the following hypothesis regarding the perception of CSR and quality management activities: 


\section{Hypothesis 2}

Public performance center CEOs' perception of corporate social responsibility will have a positive effect on quality management activities.

\section{The relationship between social capital and quality management activities}

Social capital is understood as a resource derived from social relationship structures, and is accessible and available for certain behaviors or purposes (Lin et al. 2001). The definition of social capital is varied in accordance with various academic traditions, level of analyses and focus of research, and its effect sites also run the gamut from human resources development and firm performance to regional or national prosperity (Huh 2011). Nevertheless, the fundamental focal point of social capital is that relationship networks are valuable resources that explain social behavior. Hence, social capital has been widely utilized to illustrate social behavior or results, such as promotion (Labianca 2004), interdepartmental exchange and integration of resources within organizations (Tsai and Ghoshal 1998), team performance (Labianca 2004), creation of intellectual resources (Nahapiet and Ghoshal 1998), knowledge flow (Bell and Zaheer 2007), and knowledge sharing (Yang and Farn 2009).

The sub-dimensions of social capital are structural, relational, and cognitive dimensions (Nahapiet and Ghoshal 1998). The structural dimension refers to the type of actors' overall network, including network ties and network configuration (Nahapiet and Ghoshal 1998). The relational dimension is specified as the relational characteristics formed and developed between individuals via interdependent processes (Granovetter 1992), and the cognitive dimension is defined as facilitating an understanding of things or common behavior patterns through shared goals, values, languages or meanings (Coleman 1988).

It is believed that social capital prompts the development of intellectual resources within an organization by affecting the conditions required for the exchange and integration of knowledge (Nahapiet and Ghoshal 1998). Social capital is based on the premise that network ties allow access to useful resources. Social network is the path through which information and knowledge flow, thereby facilitating exchanges of knowledge (Uzzi 1996; Hansen 1999; Levin and Cross 2004).

An organization's innovative capacity largely dictates its ability to utilize intellectual resources. Several preceding studies on innovation have focused on the creation or use of knowledge, and those studies on knowledge or intellectual resources set innovation as the key outcome variable (Ahuja 2000; Subramaniam and Youndt 2005; Collins and Smith 2006; Frenz and Ietto-Gillies 2009; Zhang et al. 2009). This implies that knowledge creation and innovation are closely related. Innovation is a result of the interdependence and exchange of knowledge among various actors, as well as the convergence of different knowledge (Landry et al. 2002; Zheng 2010). Products and services are developed through such exchanges of knowledge (Hargadon and Sutton 1997). Summarizing the points discussed thus far, innovation is a process in which organizations solve problems through an accumulation of new knowledge, and knowledge creation is an integral part of innovation (Smith et al. 2005; Subramaniam and Youndt 2005).

Quality management spotlights gaining competitive advantages through achieving quality. It puts weight on customer satisfaction, human respect, and social contribution, while encouraging all members of the organization to utilize all available means to innovate and 
improve business to increase competitiveness, ultimately targeting to achieve organizational objectives (Kim et al. 2007). Drawing on this purpose of quality management, it is clear that innovation is a critical factor in quality management. All things considered, social capital is a condition required for the exchange and integration of knowledge, which prompts the creation of new knowledge and innovation. As we have discussed, innovation is an important factor in quality management, thereby suggesting that social capital comprises a significant portion of quality management. Therefore, we established the following hypothesis regarding social capital and quality management activities:

\section{Hypothesis 3}

The social capital of public performance center CEOs will have a positive effect on quality management activities.

The relationship between quality management activities and business performance

Quality management has a considerable effect on firms' profitability, productivity and quality (Bou-Llusar et al. 2009), in addition to accomplishing performance (Gallear and Ghobadian 2004). Furthermore, previous studies revealed that the various methods of quality improvement via quality management improve operational and financial performance as well (Saravanan and Rao 2007). Schriesheim and Cogliser (2009) argued that quality management is not only confined to the production stages (e.g., process control and inspection), but is extended to envelop the overall operations of a firm, from designing products that meet customer demands to establishing corporate culture that underscores quality. In addition, the difference in business performance between firms using quality as a competitive weapon and those that are not has been identified in a strategic perspective.

Adam (1994) analyzed that various regulatory approaches for quality management improved the operating performance and financial results. Lawler et al. (1992) conducted a study on 100 American companies to measure quality management activity by using the elements of productivity, quality, customer service, competitiveness, profitability, worker satisfaction, job transfer result, and quality working condition. Such quality management activity was found to enhance the market share and profit margin, which are the operating performances. Furthermore, Zairi (2012) conducted empirical study that indicated that executing quality management activity have positive effect on the market share and profit margin. In this relationship, the variables of quality management execution were shown to have an important role.

Hence, we established the following hypotheses regarding quality management and business performance:

\section{Hypothesis 4}

The quality management activities performed by public performance center CEOs will have a positive effect on market performance.

\section{Hypothesis 5}

The quality management activities performed by public performance center CEOs will have a positive effect on financial performance. 


\section{Data collection and construct measurement Measuring variables}

The core constructs of this study comprise five factors: public performance center CEOs' entrepreneurship, social responsibility and social capital, and the performance centers' quality management and business performance. Entrepreneurship was assessed with a measurement scale developed by Matsuno et al. (2002) that was modified and supplemented for the use of this study. A 5-point Likert scale was used to measure a total of nine questions: innovativeness (3 questions), risk taking (3 questions), and proactiveness (3 questions). Social responsibility was assessed with a measurement scale developed by Carroll (1979) that was modified and supplemented for the use of this study. A 5-point Likert scale was used to measure a total of eight questions: economical dimension (2 questions), legal dimension (2 questions), ethical dimension (2 questions), and charitable dimension (2 questions). Of note, social responsibility was renamed to "perception of social responsibility" for the purpose of this study. Social capital was assessed with a measurement scale developed by Watson (2007) that was modified and supplemented for the use of this study, and a total of eight questions were measured on a 5-point Likert scale. Quality management activities of public performance centers were assessed with a measurement scale developed by Gallear and Ghobadian (2004) that was modified and supplemented for the use of this study. With two questions per each dimension (performance management, process management, training management, and customer management), a total of eight questions were measured on a 5-point Likert scale. Business performance was assessed with a measurement scale developed by Kwon (2010) that was modified and supplemented for the use of this study, measuring four items regarding market performance on a 5-point Likert scale; financial performance was measured in four areas (annual budget, annual corporate subsidy, annual sales, and annual net income) using the values in the corporate disclosures.

In addition, entrepreneurship, perception of social responsibility, and quality management were further divided into applicable sub-dimensions and the sum of each measured item was used for the assessment. The details on the specific measured items are presented in the Appendix.

\section{Research subjects and data collection}

This study was conducted on the CEOs of Korea's 170 national or public performance centers or local culture and arts centers that are listed as members of The Korean Cultural and Arts Centers Association (KOCACA). The questionnaires were conducted on the CEOs via phone and emails/fax or face-to-face interviews depending on the location of the subjects' institution over the course of three weeks from March 4, 2013 to March 23, 2013. There were five performance centers without a CEO during the data collection period due to the termination of contracts, and two CEOs were absent due to a long-term business trip oversees. We also eliminated additional 35 performance centers for various reasons; some were KOCACA members but did not have a performance facility; some CEOs refused interviews because their institutions were strictly for city hall or students' educational use, while some CEOs of city or military-run institutions declined interviews because they did not think their responses would be beneficial for the purpose of this study, as they were 
public officials who were newly appointed as representatives and have no direct knowledge in the culture and arts field.

As a result, a total of 103 questionnaires were collected. Five questionnaires were additionally eliminated for insincere or incomplete answers, resulting in a total of 98 effective questionnaires $(95.1 \%)$ for analysis. The general characteristics of the samples are illustrated in Table 1.

As illustrated in Table 1, the respondents were mostly male (88, $89.8 \%$ ), above the $50 \mathrm{~s}(85,86.7 \%)$, and with education beyond undergraduate degrees (78, $79.6 \%)$. Only 14 subjects (14.3\%) majored in the arts or physical education, with the majority being non-arts majors $(84,85.8 \%)$; there were more subjects with fewer than 10 years of experience $(54,55.1 \%)$ than those with more than 10 years of experience $(44,44.9 \%)$, and incumbency was mostly under 5 years $(85,86.7 \%)$. With regards to performance centers, most of them were medium-sized (43, 34.9\%) and had 500-1000 seat capacity (55, $5.1 \%), 10-20$ employees (33, $33.7 \%$ ), and annual audience of more than 100,000 people (41, $41.8 \%)$.

\section{Reliability and validity}

This study tested causal relationships through structural equation modeling analysis. The structural equation presents the advantage that the relevance of a number of variables can be tested within a single model. Therefore, a researcher would use structural equation when having assumption of the various relationships between parameters. Furthermore, the structural equation is expressed in a way that complex relationships between the variables are easily visualized. This study used LISREL Ver. 8.72 to test hypothesis. To test reliability and validity of the measured items, convergent validity, discriminant validity, and reliability analysis were performed.

We conducted various analyses to verify the convergent validity, discriminant validity, and reliability of the constructs. Table 2 is an illustration of the correlation coefficients and Cronbach's $\alpha$ values for the constructs determined by the confirmatory factor analysis using LISREL Ver. 8.72 Table 3 shows the loading values, composite reliability and average variance extracted values of the measurement model.

The loading values $(\lambda)$ of all constructs were significantly high. Moreover, the composite reliability of all constructs was greater than the minimum threshold of 0.6. The average variance extracted (AVE) was also shown to be greater than the minimum threshold of 0.5 for all constructs except for entrepreneurship. Likewise, Cronbach's $\alpha$ values were shown to be above the minimum threshold of 0.7 for all constructs except for entrepreneurship. These results confirmed the convergent validity of all constructs. To verify the discriminant validity, we followed the testing method proposed by Anderson and Gerbing (1988), and performed chi square difference test for the constrained models (correlation coefficient of all constructs constrained to 1.0) and unconstrained model. The $\chi^{2}$ values of the constrained and unconstrained models were $902.27(\mathrm{df}=252, p=0.00)$ and 440.84 $(\mathrm{df}=237, p=0.00)$, respectively. The difference of $\chi^{2}$ was $461.43(\Delta \mathrm{df}=15)$, which was statistically significant. The results confirmed adequate discriminant validity for all constructs included in our research model. 
Table 1 General characteristics of the samples

\begin{tabular}{|c|c|c|c|c|c|c|c|}
\hline Item & & Frequency & $\begin{array}{l}\text { Percentage } \\
(\%)\end{array}$ & Item & & Frequency & $\begin{array}{l}\text { Percentage } \\
(\%)\end{array}$ \\
\hline \multirow[t]{2}{*}{ Gender } & Male & 88 & 89.8 & Age & Under 40s & 13 & 13.3 \\
\hline & Female & 10 & 10.2 & & Above 50s & 85 & 86.7 \\
\hline \multirow[t]{2}{*}{ Educational background } & Below undergraduate graduation & 20 & 20.4 & Undergraduate major & Arts/Physical Education & 14 & 14.3 \\
\hline & $\begin{array}{l}\text { Beyond undergraduate } \\
\text { graduation }\end{array}$ & 78 & 79.6 & & Commerce & 13 & 13.3 \\
\hline \multirow[t]{2}{*}{ Amount career experience } & Less than 10 years & 54 & 55.1 & & & & \\
\hline & More than 10 years & 44 & 44.9 & & Humanities/ Social & 38 & 38.8 \\
\hline \multirow[t]{2}{*}{ Incumbency } & Less than 5 years & 85 & 86.7 & & sciences & & \\
\hline & More than 5 years & 13 & 13.3 & & Others & 33 & 33.7 \\
\hline \multirow[t]{3}{*}{ Size of performance center } & Large & 39 & 39.8 & Seat capacity & Less than 500 seats & 19 & 19.4 \\
\hline & Medium & 43 & 43.9 & & $500-1000$ seats & 55 & 56.1 \\
\hline & Small & 14 & 14.3 & & More than 1000 seats & 24 & 24.5 \\
\hline \multirow[t]{6}{*}{ Number of employees } & Less than 10 & 20 & 20.4 & Annual audience & Less than 10,000 people & 7 & 7.1 \\
\hline & $10-20$ & 33 & 33.7 & & 10,000-30,000 people & 13 & 13.3 \\
\hline & $20-30$ & 12 & 12.2 & & $30,000-50,000$ people & 14 & 14.3 \\
\hline & & & & & 50,000-70,000 people & 10 & 10.2 \\
\hline & $30-50$ & 16 & 16.3 & & 70,000-100,000 people & 13 & 13.3 \\
\hline & More than 50 & 17 & 17.4 & & More than 100,000 people & 41 & 41.8 \\
\hline \multirow{2}{*}{$\begin{array}{l}\text { Total number of performance centers in Korea } \\
\text { (As of March, 2013) }\end{array}$} & National or public & 162 & 94.2 & \multirow{2}{*}{$\begin{array}{l}\text { Miscellaneous (Data } \\
\text { collection) }\end{array}$} & National or public & 94 & 96.0 \\
\hline & Private (firm) & 10 & 5.8 & & Private (firm) & 4 & 4.0 \\
\hline
\end{tabular}


Table 2 Correlation coefficients of the constructs

\begin{tabular}{|c|c|c|c|c|c|c|}
\hline Variable & Entrepreneurship & $\begin{array}{l}\text { Social } \\
\text { responsibility } \\
\text { (Perception }\end{array}$ & $\begin{array}{l}\text { Social } \\
\text { capital }\end{array}$ & $\begin{array}{l}\text { Quality } \\
\text { management } \\
\text { activities }\end{array}$ & $\begin{array}{l}\text { Market } \\
\text { performance }\end{array}$ & $\begin{array}{l}\text { Financial } \\
\text { performance }\end{array}$ \\
\hline Entrepreneurship & 0.61 & & & & & \\
\hline $\begin{array}{l}\text { Social responsibility } \\
\text { (Perception) }\end{array}$ & $\begin{array}{l}0.72 \\
(8.30)\end{array}$ & 0.79 & & & & \\
\hline Social capital & $0.52(5.06)$ & $0.50(5.42)$ & 0.85 & & & \\
\hline $\begin{array}{l}\text { Quality management } \\
\text { activities }\end{array}$ & $0.83(11.78)$ & $0.75(12.13)$ & $\begin{array}{l}0.62 \\
(8.06)\end{array}$ & 0.91 & & \\
\hline Market performance & $0.48(4.57)$ & $0.60(7.56)$ & $\begin{array}{l}0.47 \\
(5.20)\end{array}$ & $\begin{array}{l}0.71 \\
(11.74)\end{array}$ & 0.89 & \\
\hline Financial performance & $0.45(4.24)$ & $0.45(4.79)$ & $\begin{array}{l}0.50 \\
(5.82)\end{array}$ & $\begin{array}{l}0.56 \\
(7.07)\end{array}$ & $\begin{array}{l}0.46 \\
(5.25)\end{array}$ & 0.92 \\
\hline Mean & 3.587 & 4.216 & 3.61 & 3.723 & 3.801 & 3.479 \\
\hline Standard deviation & 0.546 & 0.481 & 0.651 & 0.682 & 0.738 & 2.107 \\
\hline
\end{tabular}

(Inside the parentheses are the t-values, diagonal values are the Cronbach's a)

Table 3 Results of the measurement model analysis

\begin{tabular}{|c|c|c|c|c|c|c|}
\hline Variable & Question & $\begin{array}{l}\text { Loading } \\
\text { value }(\lambda)\end{array}$ & $\begin{array}{l}\mathrm{t}- \\
\text { value }\end{array}$ & $\begin{array}{l}\text { Squared multiple } \\
\text { correlation }\end{array}$ & $\begin{array}{l}\text { Composite } \\
\text { reliability }\end{array}$ & AVE \\
\hline \multirow[t]{3}{*}{ Entrepreneurship } & INN & 0.80 & 8.09 & 0.640 & \multirow[t]{3}{*}{0.645} & \multirow[t]{3}{*}{0.389} \\
\hline & FOR & 0.49 & 4.64 & 0.240 & & \\
\hline & RIS & 0.53 & 5.15 & 0.281 & & \\
\hline \multirow{4}{*}{$\begin{array}{l}\text { Social responsibility } \\
\text { (Perception) }\end{array}$} & ECO & 0.76 & 8.39 & 0.578 & \multirow[t]{4}{*}{0.824} & \multirow[t]{4}{*}{0.544} \\
\hline & LAW & 0.74 & 8.00 & 0.548 & & \\
\hline & ATH & 0.84 & 9.57 & 0.706 & & \\
\hline & $\mathrm{CHA}$ & 0.59 & 5.98 & 0.348 & & \\
\hline \multirow[t]{5}{*}{ Social capital } & SOC1 & 0.62 & 6.39 & 0.384 & \multirow[t]{5}{*}{0.853} & \multirow[t]{5}{*}{0.541} \\
\hline & SOC2 & 0.74 & 8.15 & 0.548 & & \\
\hline & $\mathrm{SOC3}$ & 0.64 & 6.67 & 0.410 & & \\
\hline & SOC4 & 0.88 & 10.44 & 0.774 & & \\
\hline & SOC5 & 0.76 & 8.46 & 0.578 & & \\
\hline \multirow{4}{*}{$\begin{array}{l}\text { Quality management } \\
\text { activities }\end{array}$} & PER & 0.89 & 11.07 & 0.792 & \multirow[t]{4}{*}{0.882} & \multirow[t]{4}{*}{0.653} \\
\hline & PRO & 0.80 & 9.20 & 0.640 & & \\
\hline & EDU & 0.78 & 8.90 & 0.608 & & \\
\hline & CUS & 0.76 & 8.62 & 0.578 & & \\
\hline \multirow[t]{4}{*}{ Market performance } & MPF1 & 0.69 & 7.53 & 0.476 & \multirow[t]{4}{*}{0.902} & \multirow[t]{4}{*}{0.698} \\
\hline & MPF2 & 0.85 & 10.14 & 0.723 & & \\
\hline & MPF3 & 0.92 & 11.68 & 0.846 & & \\
\hline & MPF4 & 0.87 & 10.51 & 0.757 & & \\
\hline \multirow[t]{4}{*}{ Financial performance } & OBU & 0.87 & 10.60 & 0.757 & \multirow[t]{4}{*}{0.927} & \multirow[t]{4}{*}{0.758} \\
\hline & CSU & 0.81 & 9.47 & 0.656 & & \\
\hline & SAL & 0.91 & 11.38 & 0.828 & & \\
\hline & PIN & 0.90 & 11.35 & 0.810 & & \\
\hline
\end{tabular}


This study examines the relationship among the characteristics of public performance center CEOs, quality management, and business performance. We measured all variables only from the self-report questionnaires from CEOs, thereby resulting in a possibility of common method bias. If there is a severe common method variance, it may undermine the validity of the results and affect the relationship among the variables within the research model, producing distorted results (Park et al. 2007). Hence, we checked for any common method variance via two methods. Based on the upper echelons perspective theory introduced by Hambrick and Mason (1984), the variables that can be observed by an upper echelon, such as age, educational background, undergraduate major, career experience, and years of work experience, and the relationship between independent variables and dependent variables were analyzed. Furthermore, based on methods presented by the study of Podsakoff and Organ (1986), single-factor test by Harman (1967) was conducted.

To analyze the relationship between the observable variables and this study's constructs, a regression analysis was performed with the subjects' age, educational background, undergraduate major, career experience, and incumbency as the independent variables and entrepreneurship, perception of social responsibility, social capital, quality management activities, market performance, and financial performance as the dependent variables. The results indicated that all relationships among variables, except that between career experience and social capital, were insignificant with a level of significance below the threshold of 0.5. Furthermore, performing an unrotated factor analysis as suggested by Podsakoff and Organ (1986) revealed 7 factors with eigenvalues greater than 1.0; of these factors, the first factor accounted for $37.33 \%$ of the total variance, thus the common method bias was deemed insignificant (Huh 2006; Park et al. 2007; Shim et al. 2010).

\section{Hypotheses testing}

The correlation coefficients between the constructs shown in Table 2 are positively significant at $p=.01$. Performance centers' market performance and financial performance had a highest correlation with quality management activities of the CEO, and also a significant correlation with entrepreneurship, perception of social responsibility, and social capital at $p=.01$. In addition, the CEOs' quality management activities had the strongest correlation with entrepreneurship, and perception of social responsibility and social capital also showed a high correlation.

Table 4 illustrates the main estimates for constructs and the test results for our hypotheses.

As illustrated in Table 4, the structural model that estimated the path coefficients was well-fitted overall (Chi-Square $=44.15(p=0.00, \mathrm{df}=238, \mathrm{GFI}=0.87, \mathrm{NFI}=0.91$, $\mathrm{CFI}=0.95, \mathrm{IFI}=0.95, \mathrm{RMR}=0.076, \mathrm{RMSEA}=0.077)$. The results of the significance tests are as follows. First, hypotheses 1, 2 and 3 were accepted, as the characteristics of public performance center CEOs, namely entrepreneurship $(\beta=0.53, t=3.14$, $p \leq .01)$, perception of social responsibility $(\beta=0.26, t=1.72, p \leq .1)$, and social capital $(\beta=0.21, t=2.06, p \leq .05)$, were shown to have a significantly positive effect on quality management activities. 
Table 4 Results of the structural model analysis

\begin{tabular}{|c|c|c|c|c|}
\hline \multirow{3}{*}{$\begin{array}{l}\text { Relationship } \\
\text { Entrepreneurship } \rightarrow \text { Quality management }\end{array}$} & \multicolumn{2}{|l|}{ Estimate } & \multirow{2}{*}{\multicolumn{2}{|c|}{$\begin{array}{l}\text { Hypothesis } \\
\text { acceptance }\end{array}$}} \\
\hline & \multirow{2}{*}{$\begin{array}{l}\text { ML estimate } \\
0.53\end{array}$} & \multirow{2}{*}{$\begin{array}{l}\text { t-value } \\
3.14\end{array}$} & & \\
\hline & & & $\mathrm{H} 1$ & Accepted \\
\hline Social responsibility (perception) $\rightarrow$ Quality management & 0.26 & 1.72 & $\mathrm{H} 2$ & Accepted \\
\hline Social capital $\rightarrow$ Quality management & 0.21 & 2.06 & $\mathrm{H} 3$ & Accepted \\
\hline Quality management $\rightarrow$ Market performance & 0.89 & 3.01 & $\mathrm{H} 4$ & Accepted \\
\hline Quality management $\rightarrow$ Financial performance & 0.47 & 1.88 & H5 & Accepted \\
\hline Goodness of fit of the model & \multicolumn{4}{|c|}{$\begin{array}{l}\text { Chi-Square }=441.15(p=0.00, \mathrm{df}=238), \mathrm{GFI}=0.87, \\
\mathrm{NFI}=0.91, \mathrm{CFI}=0.95, \mathrm{IFI}=0.95, \mathrm{RMR}=0.076, \\
\mathrm{RMSEA}=0.077\end{array}$} \\
\hline
\end{tabular}

Moreover, hypotheses 4 and 5 were also accepted, as quality management activities were shown to have a significantly positive effect on business performance, namely market performance $(\beta=0.89, t=3.01, p \leq .01)$ and financial performance $(\beta=0.47, t=1.88, p \leq .1)$.

In summary, the study's findings exhibit that the characteristics of public performance center CEOs (i.e., entrepreneurship, perception of social responsibility, and social capital) have a positive effect on quality management activities, and quality management activities in turn wield a positive effect on business performance (i.e., market and financial performance).

\section{Conclusions and discussions}

The objective of this study is to provide logical grounds and empirical findings to determine if the characteristics of public performance center CEOs (i.e., entrepreneurship, social responsibility-perception, and social capital) and quality management can enhance business performance; more specifically, we sought to probe whether these factors equally affect business performance of public performance centers and general firms. To this end, we established several hypotheses and tested these hypotheses by collecting and analyzing questionnaires from a sample of 98 Korean public performance center CEOs.

As we have hypothesized, the characteristics of public performance center CEOs have been confirmed to have a positive effect on quality management activities. More specifically, entrepreneurship had a positive effect on quality management activities, which supports a claim from a previous study that entrepreneurship should be considered as a context variable or an antecedent that promotes quality management activities (Lawler et al. 1992). Moreover, perception of social responsibility had a positive effect on quality management as well, which supports previous study results that the perception of social responsibility is in line with the purpose of publicness (Lee 2009a), as it is a corporate activity that raises stakeholders' value (Donaldson and Preston 1995). Finally, the last sub-dimension of CEOs' characteristics, social capital, was also found to have a positive effect on quality management, confirming previous study findings that social capital creates knowledge exchange and integration to boost an organization's intellectual capital (Nahapiet and Ghoshal 1998), ultimately expanding the organization's innovative capacity (Levin and Cross 2004). 
In the hypothesis of this study, the following previous studies are supported: studies by Shin et al. (1998), Schriesheim and Cogliser (2009) which are related to entrepreneurship and quality management activity; studies by Brown and Dacin (1997), Sen and Bhattacharya (2001), which are related to social responsibility and quality management activity; and studies by Smith et al. (2005), Subramaniam and Youndt (2005) which are related to social capital and quality management activity.

Additionally, quality management activities were found to have a positive effect on business performance (i.e., market and financial performance). This finding confirms previous studies that suggested quality management as a key player in performance enhancement (Saravanan and Rao 2007; Schriesheim and Cogliser 2009), as well as accentuating the significance of quality management in art management as much as in general corporate management.

This study has the several practical implications. First, quality management can improve business performance. This underscores the fact that art management should be approached in the same manner as corporate management. However, art management has been strictly differentiated from corporate management due to the specificity of "arts". This has been a limiting factor that impedes further advancement of the culture and arts industry. Furthermore, because public performance centers have been placing priority on achieving publicness, that is, improving the quality of lives of local residents by satisfying their culture and arts needs (Lee 2009b), several problems have arisen due to sluggish profitability (Lee and Chung 2010). Public performance centers have suffered staggering blows to its operations and functions because their local autonomy-run operating systems lack adequate expertise in performance center operations and culture and arts, and also lack complete fiscal independence (Lee and Chung 2010). As a result, the very existence of public performance centers as the center of local culture and arts is at risk. These circumstances all the more call for a perception that art management and corporate management have a certain degree of similitude, as well as the implementation of quality management in the arts field to increase operational efficiency.

Second, certain characteristics, such as entrepreneurship and social capital, are demanded of public performance center CEOs to promote quality management. These characteristics determine the success of quality management, as the CEO's utmost support is critical to achieving the goals of quality management (Lawler et al. 1992). Notably, an arts CEO has two crucial roles: influencing creative activities and generating profit from the creative production (Goo and Lee 2012). In other words, the CEO must not only perform artistic activities but also promote profit by meeting customers' needs (Rae 2005). Therefore, an arts CEO should be equipped with the entrepreneurial capacity, such as entrepreneurship and social capital. Entrepreneurship, namely innovativeness, risk-taking tendency and proactiveness, allows an arts CEO to acquire a new market by anticipating consumers' needs in culture and arts, during which social capital helps to harness intellectual resources that mitigate uncertainty and increase competitiveness (Goo and Lee 2012).

Finally, an arts CEO should acknowledge the importance of achieving the goal of publicness. Publicness in art management manifests as the maximization of 
enjoyment of arts. For the purpose of realizing publicness, the role of social responsibility (or the perception of) is quite significant. The social responsibility of public performance centers facilitates cultural and artistic productions in the local community and provides more access for the local residents to enjoy culture and arts, ultimately enhancing their quality of life. Although only the non-profit aspects of such social responsibility activities are usually magnified, there may be long-term profitable implications to social responsibility (Carroll 1991). Hence, public performance center CEOs should take a long-term standpoint in terms of ameliorating profitability of their performance centers and continue with efforts to fulfill social responsibility.

Despite the several theoretical and practical implications, this study is limited due to the following.

First, although we surveyed CEOs nationwide, the absolute number of samples is small. The generalization of our findings is further hampered by the specificity of public performance centers; that is, general (private) performance centers may have different contributory factors to business performance. Therefore, future studies should investigate a wider pool of samples.

Second, the characteristics of public performance CEOs were confined to entrepreneurship, social responsibility (perception), and social capital. However, previous studies have suggested other characteristics of a CEO that affect quality management, such as leadership (Eskildson 1994) and knowledge and learning (Kathuria 2000). Hence, future studies should examine more diverse characteristics.

Third, the effect of quality management activity on management performance was analyzed, but it has limitation in measuring dual financial performances. The financial performances are measured as annual budget estimation, subsidy budget for enterprises, sales amount, and net income amount. However, these are not officially declared quantified measurement, and they are estimations based on the respondents' standards. Therefore, these have limitations to be considered as measurement for representative management performance. In the future, the management performance should be measured by using quantified financial performances, to find the effect of quality management activity on management performances through empirical analysis.

Fourth, a longitudinal study was needed in order to find the market performance and financial results with time, for the public art performance centers. However, this was a cross-sectional study due to many limitations regarding study environment, time constraints, etc. Therefore, a longitudinal study should be conducted in the future.

Finally, although we set innovativeness, risk-taking, and proactiveness as subdimensions of entrepreneurship, some studies established these characteristics as separate constructs and analyzed their relationships with other constructs (Hughes and Morgan 2007). Moreover, many management researches established the sub-dimensions of social responsibility and social capital as separate constructs as well. Thus, future researchers should attempt to more accurately define the conceptual definitions of entrepreneurship, social responsibility, and social capital by probing each of the suggested sub-dimensions to find if they display any independent relationships with other variables. 


\section{Appendix}

Evaluation items in the questionnaire

\begin{tabular}{|c|c|c|}
\hline \multicolumn{2}{|l|}{ Variable } & \multirow{2}{*}{$\begin{array}{l}\text { Evaluation items } \\
\text { I believe creative and new methods are more important in problem solving. }\end{array}$} \\
\hline Entrepreneurship & Innovativeness & \\
\hline & & I desire to execute creative marketing strategies. \\
\hline & & $\begin{array}{l}\text { I believe even previously successful products and services should be } \\
\text { changed according to market conditions. }\end{array}$ \\
\hline & Proactiveness & I believe changes in the market create positive opportunities. \\
\hline & & I think more about opportunities than risks. \\
\hline & & $\begin{array}{l}\text { I want to recommend my marketing strategies to competitors (other } \\
\text { performance centers). }\end{array}$ \\
\hline & Risk taking & I believe orderly manners and risk averting is important. (Reversed items) \\
\hline & & I want to operate the performance center safely. (Reversed items) \\
\hline & & I will invest in high-risk, high-return investments. \\
\hline \multirow{8}{*}{$\begin{array}{l}\text { Social responsibility } \\
\text { (Perception) }\end{array}$} & Economical & I try to provide good service. \\
\hline & & I aggressively invest to plan and stage a good performance/production. \\
\hline & Legal & I always try to abide by the laws and principles. \\
\hline & & I try to protect customers' rights and safety. \\
\hline & Ethical & I pay attention to ethical business practices. \\
\hline & & I pay attention to the social responsibility of performance centers. \\
\hline & Charitable & I actively return our profits to society. \\
\hline & & I personally participate in various volunteering activities. \\
\hline \multirow[t]{5}{*}{ Social capital } & & I maintain an amicable relationship with government ministries. \\
\hline & & $\begin{array}{l}\text { I maintain an amicable relationship with companies related to the } \\
\text { performance center operation. }\end{array}$ \\
\hline & & $\begin{array}{l}\text { I actively participate in various committees related to the performance } \\
\text { center operation. }\end{array}$ \\
\hline & & $\begin{array}{l}\text { I maintain an amicable relationship with non-government individuals (tax } \\
\text { accountants, accountants, management consultants, etc.). }\end{array}$ \\
\hline & & $\begin{array}{l}\text { I maintain an amicable relationship with various financial institutions } \\
\text { related to the performance center operation. }\end{array}$ \\
\hline \multirow{8}{*}{$\begin{array}{l}\text { Quality } \\
\text { management } \\
\text { activities }\end{array}$} & $\begin{array}{l}\text { Performance } \\
\text { management }\end{array}$ & $\begin{array}{l}\text { I develop and manage performance measurement indicators related to } \\
\text { the performance center operation. }\end{array}$ \\
\hline & & I perform appropriate management via business performance analysis. \\
\hline & Process & I actively improve business tasks for performance improvement. \\
\hline & & I actively improve business processes to enhance business efficiency. \\
\hline & Education/ & I run various programs that help employee career development. \\
\hline & & I am vastly interested in employees' career training. \\
\hline & Customer & I reflect customers' opinions when establishing performance programs. \\
\hline & & I regularly measure customer satisfaction to reflect them in business. \\
\hline \multirow{8}{*}{$\begin{array}{l}\text { Business } \\
\text { performance }\end{array}$} & Market & I am meeting the management goals of our performance center. \\
\hline & & I am meeting the cost-reduction goals of our performance center. \\
\hline & & Our management innovation program is being carried out smoothly. \\
\hline & & The competitiveness of our performance center is increasing. \\
\hline & Financial & What is our annual budget? \\
\hline & & What is our annual corporate subsidy? \\
\hline & & What is our annual sales? \\
\hline & & What is our annual net income? \\
\hline
\end{tabular}




\section{Competing interests}

The authors declare that they have no competing interests.

\section{Authors' contributions}

All authors read and approved the final manuscript.

\section{Author details}

${ }^{1}$ Garam Education, Jam-sil the shop Starpark A-309, Shincheon-Dong 714, Songpa-Gu, Seoul, Korea. ${ }^{2}$ Kyung Hee University School of Dance, Jam-sil the shop Starpark A-309, Shincheon-Dong 714, Songpa-Gu, Seoul, Korea.

Received: 8 June 2015 Accepted: 4 August 2015

Published online: 02 September 2015

\section{References}

Adam EE. Alternative quality improvement practices and organization performance. Journal of Operations Management, 1994;12(1):27-44.

Ahuja G. Collaboration networks, structural holes, and innovation: A longitudinal study. Adm Sci Q. 2000;45(3):425-55. Anderson JC, Gerbing DW. Structural equation modeling in practice: A review and recommended two-step approach. Psychol Bull. 1988;103(3):411-23.

Baron RA, Shane SA. Entrepreneurship: A process perspective. Engage Learning. 2007.

Bell GG, Zaheer A. Geography, networks, and knowledge flow. Organ Sci. 2007;18(6):955-72

Boddy CR, Ladyshewsky RK, Galvin P. The influence of corporate psychopaths on corporate social responsibility and organizational commitment to employees. J Bus Ethics. 2010;97(1):1-19.

Bou-Llusar JC, Escrig-Tena AB, Roca-Puig V, Beltrán-Martín I. An empirical assessment of the EFQM excellence model: Evaluation as a TQM framework relative to the MBNQA model. J Oper Manag. 2009;27(1):1-22.

Bowen HR. Social responsibilities of the businessman (No. 3). New York and London: Harper and Brothers; 1953.

Brammer S, Millington A, Rayton B. The contribution of corporate social responsibility to organizational commitment. Int J Human Resour Manag. 2007;18(10):1701-19.

Brown TJ, Dacin PA. The company and the product: corporate associations and consumer product responses. J Mark. 1997;61(1):68-84.

Burgelman RA. Designs for corporate entrepreneurship. Calif Manage Rev. 1984;26(2):154-66.

Carroll AB. A three-dimensional conceptual model of corporate performance. Acad Manage Rev. 1979;4(4):497-505.

Carroll AB. The pyramid of corporate social responsibility: Toward the moral management of organizational stakeholders. Bus Horiz. 1991;34(4):39-48.

Coleman JS. Social capital in the creation of human capital. Am J Sociol. 1988;94:95-120.

Collins CJ, Smith KG. Knowledge exchange and combination: The role of human resource practices in the performance of high-technology firms. Acad Manage J. 2006;49(3):544-60.

Covin JG, Slevin DP. The development and testing of an organizational-level entrepreneurship scale. Front Entrepreneurship Res. 1986;1:626-39.

De Bruin A. Entrepreneurship in a new phase of capitalist development. J Interdiscip Econ. 1998;9:185-200.

Donaldson T, Preston LE. The stakeholder theory of the corporation: Concepts, evidence, and implications. Acad Manage Rev. 1995;20(1):65-91.

Eskildson L. Improving the odds of TQM's success. Qual Prog. 1994;27(4):61-4

Faulkner RR, Anderson AB. Short-term projects and emergent careers: Evidence from Hollywood. Am J Sociol. 1987;92(4):879-909.

Frenz M, letto-Gillies $\mathrm{G}$. The impact on innovation performance of different sources of knowledge: Evidence from the UK community innovation survey. Res Pol. 2009;38(7):1125-35.

Gallear D, Ghobadian A. An empirical investigation of the channels that facilitate a total quality culture. Total Qual Manag Bus Excell. 2004;15(8):1043-67.

Gartner WB. A conceptual framework for describing the phenomenon of new venture creation. Acad Manage Rev. 1985;10(4):696-706

Ghobadian A, Gallear DN. Total quality management in SMEs. Omega. 1996;24(1):83-106

Goetsch DL, Davis SM. Introduction to total quality: Quality, productivity. competitiveness. New York: Merrill; 1994

Goo MM. A Study on the effecting factors entrepreneurship in economic performance of cultural industries. Korean Small Bus Rev. 2008;30(4):117-38.

Goo MM, Lee HS. Intellectual capital and business performance in the cultural and creative industries: Exploring the moderating effect of the entrepreneurial orientation. J Cultural Pol. 2012;26(1):7-28.

Granovetter M. Problems of Explanation in Economic Sociology. In: Nohria N, Eccles R, editors. Networks and Organizations. Boston: Harvard University Press; 1992.

Hambrick DC, Mason PA. Upper echelons: The organization as a reflection of its top managers. Acad Manage Rev. 1984;9(2):193-206

Hansen MT. The search-transfer problem: The role of weak ties in sharing knowledge across organization subunits. Adm Sci Q. 1999:44(1):82-111.

Hargadon A, Sutton RI. Technology brokering and innovation in a product development firm. Adm Sci Q. 1997:42:716-49.

Harman HH. Modern Factor Analysis. Chicago: University of Chicago Press; 1967.

Herron L, Robinson RR. A structural model of the effects of entrepreneurial characteristics on venture performance. J Bus Venturing. 1993;8(3):281-94.

Hughes M, Morgan RE. Deconstructing the relationship between entrepreneurial orientation and business performance at the embryonic stage of firm growth. Ind Mark Manag. 2007;36(5):651-61. 
Huh MG. Strategy, environment, and manufacturing outsourcing in small and medium firms. Korean J Manag. 2006;14(3):191-229.

Huh MG. Social capital, knowledge creation, and innovation. Korean J Man. 2011;19(1):41-78.

Jeon BT, Park IB, Lee CS. Strategies for facilitating performance programs in public arts centers. South Korea: Korea Culture and Tourism Institute, Research Report; 2003.

Kamara Y. Keys to successful cultural enterprise development in developing countries, unpublished paper prepared for the global alliance for cultural diversity. Division of Arts and Cultural Enterprise. Paris: UNESCO; 2006.

Kathuria R. Competitive priorities and managerial performance: A taxonomy of small manufacturers. J Oper Manag. 2000;18(6):627-41.

Kim SJ, Kim JK. The effect of corporate social responsibility on corporate image: The role of spillover effect and negativity effect based on CSR dimensions. Asia Mark J. 2010;11(4):49-67.

Kim NM, Yoon SJ. The interaction between perceived quality and corporate social responsibility: A difference between public entities and private enterprises. J Prod Res. 2011;29(5):77-88.

Kim IH, Ku TY, Choi GS. Certification of quality management system and firm performance: An empirical approach based on the experiences of small and medium enterprises (SMEs) in Korea. J Soc Korea Ind Syst Eng. 2007;30(1):15-24

Kim JK, Park SR, Song HS, Kim HB, Yun DM. Effect of corporate social responsibility on service quality of chain restaurant. J Prod Res. 2011;9(1):55-65.

Ko YS. A study on the influence of CEO's characteristics upon quality management activities and performance. Korea: Doctoral Dissertation, WonKwang University Graduate, Jeollabuk-do Province; 2012.

Koivunen H, Kotro T. Value chain in the cultural sector. Barcelona, Spain: In 10th International Conference on Cultural Economics; 1998.

Kwon $\mathrm{YH}$. The study on the effect of fit between quality management and CSR to business performance. Korea J Bus Adm. 2010;23(5):2775-92.

Labianca G. Group social capital and group effectiveness: The role of informal socializing ties. Acad Manage J. 2004;47(6):860-75.

Landry R, Amara N, Lamari M. Does social capital determine innovation? To what extent? Technol Forecast Soc Chang. 2002;69(7):681-701.

Lawler EE, Mohrman SA, Ledford GE. Employee involvement and total quality management: Practices and results in Fortune 1000 companies. San Francisco: Jossey-Bass; 1992

Lee IK. Art management leadership of art center for 21st century. Seoul: Adbooks; 2006

Lee EM. A study on the present state and improvement of evaluation system for performing arts center. Korean Assoc Art Manag. 2009a;15:73-96

Lee YK. Operational status and prospect of public arts companies. J Music Application Stud. 2009b;2:57-74

Lee HJ, Chung MS. Consumers' recognition on the corporate social contribution. Korean NPO Rev. 2005;4(2):101-54.

Lee EM, Chung YK. Study on the proper management system for the regional arts center in Korea. Korean Assoc Art Manag. 2010;17:85-110.

Levin DZ, Cross Z. The strength of weak ties you can trust: The mediating role of trust in effective knowledge transfer. Manag Sci. 2004;50(11):1477-90.

Lin N, Cook KS, Burt RS. Social capital: Theory and research. New Brunswick, NJ: Transaction; 2001.

Maignan I. Consumers' perceptions of corporate social responsibilities: A cross-cultural comparison. J Bus Ethics. 2001;30(1):57-72.

Matsuno K, Mentzer JT, Özsomer T. The effects of entrepreneurial proclivity and market orientation on business performance. J Mark. 2002;66(3):18-32.

McAdam R. Life after ISO 9000: An analysis of the impact of ISO 9000 and total quality management on small businesses in Northern Ireland. Total Qual Manag. 1999;10(2):229-41.

Nahapiet J, Ghoshal S. Social capital, intellectual capital, and the organizational advantage. Acad Manage Rev. 1998;23(2):242-66

NESTA. Entrepreneurial education for the creative industries. policy briefing. London: NESTA; 2007.

Park MS, Lim SJ. A study on role dynamics in Korean film making industry during 2001-2006. Korean Manag Rev. 2008;37(6):1631-49.

Park WW, Kim MS, Jeong SM, Huh KM. Cause and remedies of common method bias. Korean J Manag. 2007;15(1):89-133.

Podsakoff PM, Organ DW. Self-reports in organizational research: Problems and prospects. J Manag. 1986;12(4):531-44

Preuss L, Haunschild A, Matten D. The rise of CSR: implications for HRM and employee representation. Int J Hum Resour Manag. 2009;20(4):953-73.

Rae D. Cultural diffusion: A formative process in creative entrepreneurship? Int J Entrepreneurship Innov. 2005:6(3):185-92.

Saravanan R, Rao KS. The impact of total quality service age on quality and operational performance: An empirical study. TQM Mag. 2007:19(3):197-205

Schriesheim CA, Cogliser CC. Construct validation in leadership research: Explication and illustration. Leadersh Q. 2009:20(5):725-36.

Sen S, Bhattacharya CB. Does doing good always lead to doing better?: Consumer reactions to corporate social responsibility. J Mark Res. 2001;38(2):225-43.

Shim DS, Yang DM, Ha SW. The mediating effects of psychological empowerment in the relationships between job characteristics, locus of control and leader-member exchange, and job performance. Korean J Manag. 2010;18(3):175-215

Shin D, Kalinowski JG, Abou El-Enein G. Critical implementation issues in total quality management. SAM Adv Manag J. 1998:63:10-4.

Smith KG, Collins CJ, Clark KD. Existing knowledge, knowledge creation capability, and the rate of new product introduction in high-technology firms. Acad Manage J. 2005:48(2):346-57.

Stevenson HH, Jarillo JC. A paradigm of entrepreneurship: Entrepreneurial management. Strateg Manag J. 1990;11(5):17-27. 
Subramaniam MA, Youndt M. The influence of intellectual capital on the types of innovative capabilities. Acad Manage J. 2005:48(3):450-63.

The Korean Cultural and Art Centers Association. 2013. http://www.kocaca.or.kr

Tsai W, Ghoshal S. Social capital and value creation: The role of intrafirm networks. Acad Manage J. 1998;41(4):464-76.

Uzzi B. The sources and consequences of embeddedness for the economic performance of organizations: The network effect. Am Sociol Rev. 1996;61(4):674-98.

Watson J. Modeling the relationship between networking and firm performance. J Bus Ventur. 2007;22(6):852-74

Wilson N, Stokes D. Cultural entrepreneurs and creating exchange. J Res Mark Entrepreneurship. 2002;4(1):37-52.

World Business Council for Sustainable Development (WBCSD). Corporate social responsibility: Meeting changing expectations. Conches-Geneva: World Business Council for Sustainable Development; 1999.

Yang SC, Farn CK. Social capital, behavioural control, and tacit knowledge sharing-A multi-informant design. Int J Inf Manag. 2009;29(3):210-8.

Zairi M. Measuring performance for business results. Springer Science \& Business Media. 2012.

Zhang J, Di Benedetto CA, Hoenig S. Product development strategy, product innovation performance, and the mediating role of knowledge utilization: Evidence from subsidiaries in China. J Int Mark. 2009;17(2):42-58.

Zheng W. A social capital perspective of innovation from individuals to nations: Where is empirical literature directing us? Int J Manag Rev. 2010;10(4):1-39.

Submit your manuscript to a SpringerOpen ${ }^{\circ}$ journal and benefit from:

- Convenient online submission

- Rigorous peer review

- Immediate publication on acceptance

- Open access: articles freely available online

- High visibility within the field

- Retaining the copyright to your article

Submit your next manuscript at $>$ springeropen.com 